Article

\title{
An Evaluation of the Performance of a Ground-to-Air Heat Exchanger in Different Ventilation Scenarios in a Single-Family Home in a Climate Characterized by Cold Winters and Hot Summers
}

\author{
Aldona Skotnicka-Siepsiak (D) \\ Faculty of Geoengineering, University of Warmia and Mazury in Olsztyn, Heweliusza 4, 10-724 Olsztyn, Poland; \\ aldona.skotnicka-siepsiak@uwm.edu.pl; Tel.: +48-89-523-45-76
}

check for

updates

Citation: Skotnicka-Siepsiak, A. An Evaluation of the Performance of a Ground-to-Air Heat Exchanger in Different Ventilation Scenarios in a Single-Family Home in a Climate Characterized by Cold Winters and Hot Summers. Energies 2022, 15, 105. https://doi.org/10.3390/en15010105

Academic Editor: Jose A

Almendros-lbanez

Received: 22 November 2021

Accepted: 21 December 2021

Published: 23 December 2021

Publisher's Note: MDPI stays neutral with regard to jurisdictional claims in published maps and institutional affiliations.

Copyright: (C) 2021 by the author. Licensee MDPI, Basel, Switzerland. This article is an open access article distributed under the terms and conditions of the Creative Commons Attribution (CC BY) license (https:/ / creativecommons.org/licenses/by/ $4.0 /)$.

\begin{abstract}
In the present study, the real-world performance of a ground-to-air heat exchanger (GAHE) was analyzed in the Polish climate which is characterized by warm summers and cold winters. The heat exchanger's performance was monitored over a period of three years (2017 to 2019), and real-world conditions were compared with a Typical Meteorological Year (TMY). The aim of the study was to assess the exchanger's energy-efficiency potential in various ventilation scenarios in a single-family home under variable real-world conditions, rather than to simply determine its heating and cooling capacity. The analyzed single-family home was a modern, single-story building with a usable floor area of $115 \mathrm{~m}^{2}$. The building's thermal insulation and airtightness met stringent energy-efficiency standards. Energy consumption in a building equipped with a natural ventilation system was compared with three other scenarios: ventilation coupled with a GAHE, mechanical ventilation with heat recovery and a high-efficiency heat exchanger (HE), and mechanical ventilation with heat recovery coupled with a GAHE. Sensible heating and cooling loads were calculated based on standard ISO 13790:2008, and latent heating and cooling loads were also included in the energy balance. During the year, the GAHE generated around $257.6 \mathrm{~W}$ of heating energy per hour and 124.7 W of cooling energy per hour. Presented results can be used to select the optimal HVAC system scenarios for engineering projects as well as private investors.
\end{abstract}

Keywords: ground-to-air heat exchanger; sustainable indoor ventilation system; energy-efficient ventilation

\section{Introduction}

In 2019 , the construction industry was responsible for $40 \%$ of final energy consumption in the EU27 countries [1]. Around 75\% of the heat and electricity supplied to buildings was generated from fossil fuels, and the construction sector was responsible for $36 \%$ of greenhouse gas emissions [2]. These data indicate that urgent measures are needed to decrease greenhouse gas emissions and reduce energy consumption. The concept of sustainable energy-efficient buildings has been introduced to address these concerns. Netzero exergoeconomic and exergoenvironmental buildings have attracted particular interest in Europe [3]. Energy-efficient solutions are implemented not only in new buildings but also in the existing structures. According to estimates, 75\% of European buildings are not energy efficient, and only around 1\% of structures are modernized each year [4]. Sustainable energy-efficient buildings require efficient ventilation systems to ensure high indoor environmental quality (IEQ). Indoor air quality (IAQ), thermal conditions, the occupants' health, safety, and comfort, as well as ergonomic and acoustic factors, should be considered in the process of designing an efficient ventilation system [5]. High ventilation rates generally ensure good indoor air quality, but they increase energy consumption. In an optimal solution, IAQ should be balanced with energy consumption [6].

A combination of natural ventilation approaches to free space cooling and heating is increasingly used in sustainable buildings [7]. Novel ventilation solutions are being 
proposed, including thermal buoyancy-driven ventilation (Trombe wall, double-skin façade, solar chimney or roof solar chimney, solar walls as an unglazed or glazed transpired solar facade, atrium), wind-induced ventilation (wind tower, wind catcher, fenestration as a single-side or cross ventilation or wing walls, wind cowls, rotating wind cowl and roof cowls), as well as heat modulation or amortization techniques such as nocturnal cooling applications or shifting of day heat to night for removal. Natural ventilation systems can be combined to expand their individual performance (for example, by employing pre-cooling/pre-heating ventilation to overcome extreme weather conditions), maintain stable indoor temperature (thermal mass for heat storage), recover heat energy (heat pipe and rotary thermal wheel), overcome the inadequacy of a single system (combined solarand wind-driven ventilation) and develop comprehensive energy-saving schemes that are tailored to specific building characteristics and weather conditions [7]. Solutions that combine natural ventilation with other systems and devices have attracted considerable interest in the literature [8-11], but further improvements are needed. Greater emphasis should be placed on the configuration of hybrid ventilation systems and the building's responses to optimize system design and account for the influence of wind and the local climate [7].

Natural ventilation is not an effective solution in all climates. According to Chen et al. [12], natural ventilation has the highest potential in the subtropical highland climate of South-Central Mexico, Ethiopian Highlands, and Southwest China. Natural ventilation is also effective in the Mediterranean climate that occurs not only near the Mediterranean Sea, but also in California, Western Australia, Portugal, and Central Chile. Natural ventilation systems that rely on night-time purging improve the energy efficiency of buildings in the Middle East and Central Australia. Night ventilation has considerable potential in passive and active cooling systems. This solution is particularly effective in locations characterized by high-temperature fluctuations between day and night and in buildings with heavy thermal mass construction [13]. According to research, ventilation can effectively replace air-conditioning at night [14]. Modern technologies and materials, such as phase change materials [15], ventilated internal double walls, thermosiphons, atriums, and solar chimneys, significantly contribute to the development of advanced night ventilation systems. However, hot-humid climates with warmer nights pose a certain challenge. Extreme weather events and microclimates are also problematic because they necessitate additional modifications in the designed ventilation system. The applicability of night ventilation is also limited in residential buildings due to indoor privacy and the building's operation at night [13]. Regardless of the local standards applicable to energy-efficient ventilation systems, research has demonstrated that heat recovery is essential in colder climates. Yao et al. [16] found that ventilation cooling load in China is determined by climate, the building's thermal characteristics, indoor heating and cooling loads, and ventilation requirements. Guillen-Lambea et al. [17] analyzed ventilation standards in the USA (ASHRAE Standard 62-1-2013 and ASHRAE standard 62-2-2013), Germany (DIN1946-6, DIN18018), the UK (Approved Doc. F Ventilation 2010), France (Arrêté du 24 Mars 1982 Modifié par arrêté du 28 octobre 1983), Spain (DB HS3) and Europe (UNE EN 15252), and compared them with the Passive House Standard. Ventilation systems without heat recovery met the Passive House Standard $\left(15 \mathrm{kWh} / \mathrm{m}^{2}\right.$ year) in only 5 out of the 33 analyzed cities around the world. In the remaining 28 locations, passive houses required ventilation with heat recovery. According to Laverge and Janseens [18], in comparison with natural ventilation, ventilation with heat recovery can generate net energy savings along a geographic line connecting Paris with the Black Sea. Heat recovery decreases ventilation heat loss, and effective heat recovery units should overcome pressure losses and minimize power consumption. Electric motors that drive fans in mechanical ventilation systems significantly increase power consumption. According to estimates, electric motors consume $53 \%$ of global electricity [19]. Around 38\% of electricity is consumed by fan systems, whereas the practical effectiveness of a conventional ventilation system with an electric fan is estimated at $50-65 \%$ [20]. 
Regardless of the applied ventilation system, a sustainable building should meet the following requirements: it should reduce resource consumption, promote resource reuse and recycling, protect the environment, eliminate toxins, facilitate life-cycle costing, and focus on quality [21]. Ground-to-air heat exchangers (GAHE) meet the above requirements. Various GAHE systems have been described in the literature [22-24]. Ground-to-air heat exchangers can be coupled with both mechanical $[25,26]$ and natural ventilation systems [27]. In buildings equipped with natural ventilation, GAHEs are frequently coupled with solar chimneys [28,29], but they also deliver satisfactory results in combination with solar air heaters with phase change materials [30]. A GAHE can be applied as a pre-conditioning unit to heat ventilation air in cold climates and to cool air in hot regions. These types of solutions have been found to be highly effective in diverse climates [31], including Mediterranean [32,33], monsoon [34], subtropical [35], hot and humid [36], as well as in locations such as Brazil [37], India [38], Japan [39], African [40], North America [41], Poland [42] and Turkey [43]. In regions characterized by hot summers and cold winters, such as Poland, a GAHE can function as both a pre-heating and a pre-cooling device in different seasons of the year [44].

The performance of GAHEs in the above climates has been extensively researched. In a study conducted in the hot climate of Doha, Qatar, Pakari and Ghani [45] demonstrated that a GAHE with a pipe length of $21.5 \mathrm{~m}$ and pipe diameter of $0.15 \mathrm{~m}$, buried at a depth of $0.4 \mathrm{~m}$, decreased air temperature by around $6.5^{\circ} \mathrm{C}$. A GAHE consumes around $76.5 \%$ less energy than a conventional air-conditioning system. In an experiment performed by Kaushal [46] in the Lower Himalayan Region, a GAHE with a pipe length of $60 \mathrm{~m}$ and an airflow rate of $0.5 \mathrm{~m} / \mathrm{s}$ had a cooling potential of $14.81 \mathrm{kWh}$ in summer and a maximum heating potential of $27.7 \mathrm{kWh}$ in winter. A GAHE decreases energy consumption for heating purposes by around 25-30\% [47]. Brata et al. [48] analyzed the performance of a GAHE in Timisoara, Romania. The exchanger pipe with a diameter of $0.2 \mathrm{~m}$ and a length of $35 \mathrm{~m}$ was buried at a depth of around $2 \mathrm{~m}$, and it generated around $31 \%$ of the energy consumed by the ventilation system in winter. In GAHEs with pipe length of $67-107 \mathrm{~m}$, buried in the ground at a depth of around $2 \mathrm{~m}$, and operating at airflow rates of $3000 \mathrm{~m}^{3} / \mathrm{h}, 2500 \mathrm{~m}^{3} / \mathrm{h}$, and $500 \mathrm{~m}^{3} / \mathrm{h}$ in Hamm, Fraunhofer, and Lamparter in Germany, the annual specific heating energy gain was determined in the range of 16.2 and $51.3 \mathrm{kWh} / \mathrm{m}^{2}$, whereas the annual specific cooling energy gain ranged from 12.1 to $23.8 \mathrm{kWh} / \mathrm{m}^{2}$ [49]. The results of 17 studies investigating ventilation systems coupled with GAHEs were analyzed in detail by Mihalakakou et al. [50]. The cited authors also examined the performance of GAHEs with the use of numerical methods. Numerical methods are widely applied in research to optimize the performance of GAHEs, evaluate the influence of climate, the exchanger's length and diameter, temperature, soil type, and pipe thermal conductivity [51-54].

The performance of a GAHE operating in various ventilation scenarios has been rarely analyzed in the same building under real-world conditions. Therefore, the aim of this study was to analyze the real-world performance of a GAHE in the Polish climate which is characterized by hot summers and cold winters. The energy balance was calculated, and the exchanger's energy-efficiency potential was evaluated in various ventilation scenarios in a single-family home.

\section{Materials and Methods}

Outdoor temperature, relative humidity $\left(\Theta_{\mathrm{e}}\right)$, and solar irradiance (Isol) were measured in the experimental station of the Faculty of Geoengineering of the University of Warmia and Mazury in Olsztyn. Temperature and relative humidity were also measured at the outlet $\left(\Theta_{\text {In }}\right)$ of a GAHE installed in the experimental station. The GAHE was built with the use of AwaduktThermo pipes with a diameter of $0.2 \mathrm{~m}$ that were buried in the ground at an average depth of $2.12 \mathrm{~m}$. The pipeline had a total length of $41 \mathrm{~m}$. The analyzed parameters were measured and registered at hourly intervals over a period of three years. These parameters were not registered continuously throughout the entire experiment due to short maintenance breaks, equipment failures, and downtimes scheduled for research 
purposes. In 2017, measurements were conducted over $8315 \mathrm{~h}$, and the GAHE operated for $5905 \mathrm{~h}$. In 2018, measurements were conducted over $7260 \mathrm{~h}$, the GAHE operated for $4498 \mathrm{~h}$. In 2019, measurements were conducted over $7763 \mathrm{~h}$, and the GAHE operated for $5572 \mathrm{~h}$. The Siemens QAM2120.040 duct temperature sensor with a measuring range of $-50{ }^{\circ} \mathrm{C}$ to $+80{ }^{\circ} \mathrm{C}$ was used to measure temperature at the GAHE inlet and outlet. The device has a measuring accuracy of $\pm 0.4 \mathrm{~K}$ at $0{ }^{\circ} \mathrm{C}$ and $\pm 0.5 \mathrm{~K}$ at $20^{\circ} \mathrm{C}$, and the resistance of the sensing element changes with temperature. The sensing element (LG-Ni 1000) has a nominal resistance of $1000 \Omega / 0^{\circ} \mathrm{C}$, and the time constant of the circuit during assembly in a pipeline is less than $20 \mathrm{~s}$. The Siemens QFM2100 duct sensor with a measuring range of $0 \%$ to $100 \%$ and an accuracy of $\pm 5 \%$ at $23{ }^{\circ} \mathrm{C}$ and $24 \mathrm{~V}$ AC was used to measure humidity. The analyzed GAHE was equipped with air flow meters. The measurements also involved a pyranometer with a spectral range of $300 \mathrm{~nm}$ to $2800 \mathrm{~nm}$, an output voltage of $5 \mathrm{mV} / \mathrm{W} / \mathrm{m}^{2}$ to $20 \mathrm{mV} / \mathrm{W} / \mathrm{m}^{2}$, a response time of $18 \mathrm{~s}$, and a directional error of less than $20 \mathrm{~W} / \mathrm{m}^{2}$. The airflow rate inside the GAHE was determined with the Siemens QVM62.1 air velocity sensor with a measuring range of 0 to $10 \mathrm{~m} / \mathrm{s}$ and accuracy of $\pm 0.2 \mathrm{~m} / \mathrm{s}(+3 \%$ of the measured value) at $20{ }^{\circ} \mathrm{C}, 45 \%$ humidity, and an atmospheric pressure of $1013 \mathrm{hPa}$. Sensor data were registered in real-time by a Siemens controller, and they were averaged at hourly intervals.

The results of the conducted measurements were used to determine heating and cooling loads in a single-family home (Figure 1 ). The modeled home was a single-story building with a heat transfer coefficient of $0.20\left[\mathrm{~W} /\left(\mathrm{m}^{2} \cdot \mathrm{K}\right)\right]$ for external walls, $0.15\left[\mathrm{~W} /\left(\mathrm{m}^{2} \cdot \mathrm{K}\right)\right]$ for the roof, $0.9\left[\mathrm{~W} /\left(\mathrm{m}^{2} \cdot \mathrm{K}\right)\right]$ for the windows, and $1.3\left[\mathrm{~W} /\left(\mathrm{m}^{2} \cdot \mathrm{K}\right)\right]$ for external doors. Building airtightness was determined at $1.0[1 / \mathrm{h}]$. The modeled home had a total usable floor area of $115.17 \mathrm{~m}^{2}$ and a cubic capacity of $299.44 \mathrm{~m}^{3}$. The ventilation flow rate was $150 \mathrm{~m}^{3} / \mathrm{h}$, which was sufficient to ensure 0.5 air changes per hour $[1 / \mathrm{h}]$. The amount of fresh air supplied to the building exceeded the minimum requirements to meet the inhabitants' specific needs. According to Polish standards, the minimum ventilation rates in residential buildings are set at $50 \mathrm{~m}^{3} / \mathrm{h}$ in the bathroom, $50 \mathrm{~m}^{3} / \mathrm{h}$ in the kitchen, $30 \mathrm{~m}^{3} / \mathrm{h}$ in the toilet, and $15 \mathrm{~m}^{3} / \mathrm{h}$ in the wardrobe. Indoor temperature was set at $20^{\circ} \mathrm{C}$ to guarantee thermal comfort $[55,56]$.

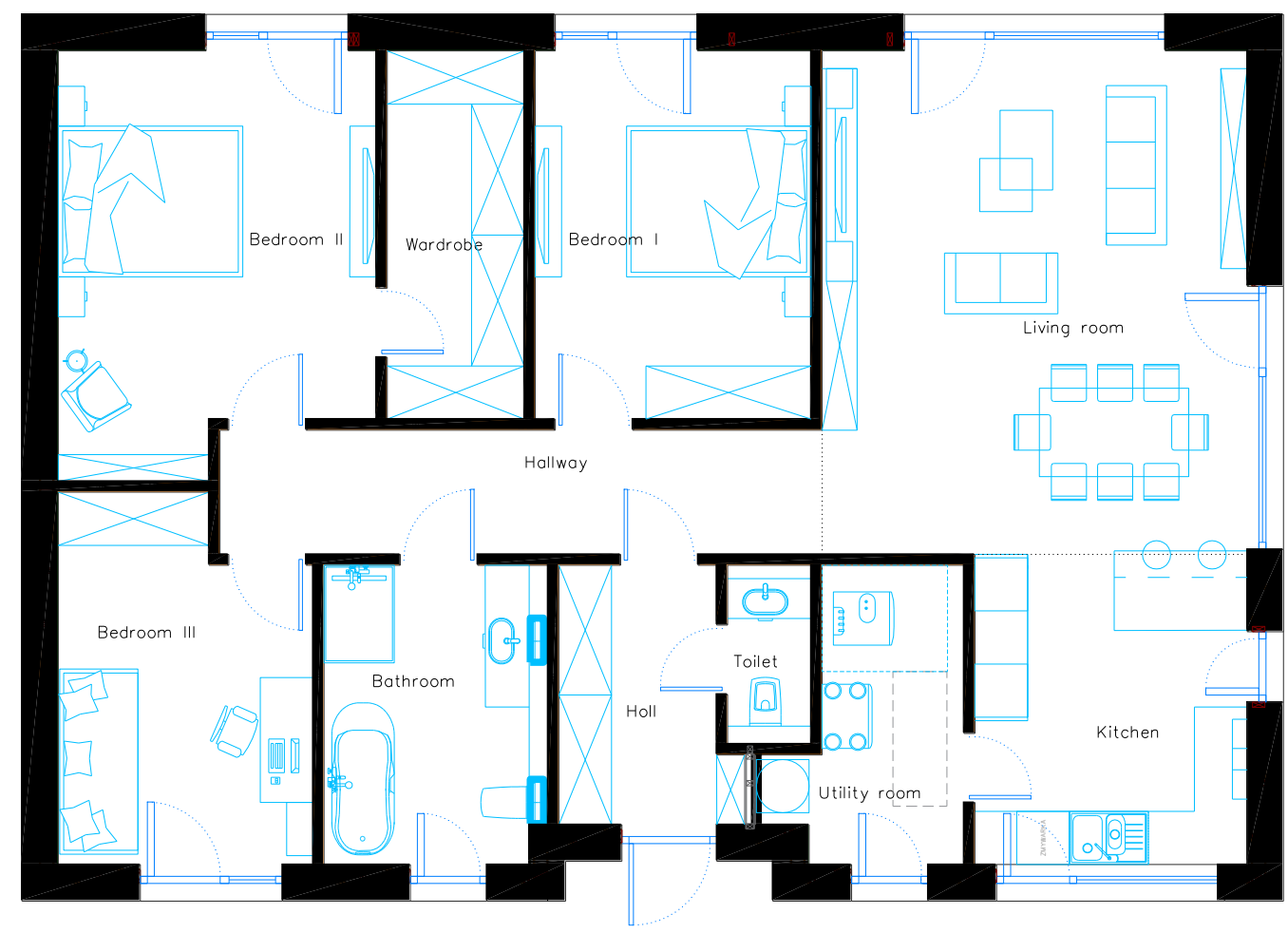

Figure 1. Floor plan of the modeled building. 
Heating and cooling loads in the building's heating, ventilation, and air-conditioning (HVAC) system were calculated in three variants:

Variant 1 -Fresh outdoor air was supplied to the building at $150 \mathrm{~m}^{3} / \mathrm{h}\left(\Theta_{\mathrm{e}}\right)$. This airflow rate is typical of natural ventilation systems. To maximize thermal comfort inside the building, heat has to be supplied (positive values in the energy balance) or removed (negative values in the energy balance) by an HVAC system.

Variant 2-The ventilation flow rate was set at $150 \mathrm{~m}^{3} / \mathrm{h}$. Fresh outdoor air passed through the GAHE before entering the building $\left(\Theta_{\text {In }}\right)$. Supply air was heated or cooled in the GAHE, and additional heat was supplied or removed by an HVAC system to obtain an indoor temperature of $20^{\circ} \mathrm{C}$. This variant is characteristic of mechanical ventilation systems without heat recovery.

Variant 3-The ventilation flow rate was set at $150 \mathrm{~m}^{3} / \mathrm{h}$. Fresh outdoor air passed through a heat exchanger (HE) with the recuperation process, that transferred heat to the incoming air supply with an efficiency of $90 \%$. When the temperature of outdoor air dropped below $0{ }^{\circ} \mathrm{C}$, incoming air was heated to $0{ }^{\circ} \mathrm{C}$ by the preliminary heater $(\mathrm{PH})$ to prevent the system from freezing. If air passing through the HE did not achieve the desired indoor temperature, it was warmed to $20^{\circ} \mathrm{C}$ by the secondary heater (SH).

Variant 4-Same as variant 3, but the system is coupled with a GAHE.

According to standard ISO 13790:2008 [57], the total hourly heat loss in a building is calculated with the use of the following formula:

$$
Q_{h t}=Q_{t r}+Q_{v e}
$$

The following equation is used to calculate total hourly heat gain:

$$
Q_{g n}=Q_{\text {int }}+Q_{\text {sol }}
$$

Internal heat gain $Q_{\text {int }}$ was not considered in the analysis because a constant value of $Q_{i n t}$ is provided for the entire year in the applicable standards. Internal heat gain is determined by specific building use (number and energy rating of household equipment, number of occupants), and it is not influenced by the weather.

The heating load $\left(Q_{B}\right)$ of the analyzed building was determined as the sum of convective heat gains and radiant heat gains through transparent partitions. The value of $Q_{B}$ is affected by the building's architectural design and weather conditions. The heating load is not influenced by the applied HVAC system.

$$
Q_{B}=Q_{t r}+Q_{s o l}
$$

In line with standard ISO 13790:2008 [57], lighting was not included in the building's energy balance.

The heating load was represented by positive values, whereas the cooling load was represented by negative values in the energy balance.

Convective heat transfer was determined with the use of the following formula:

$$
Q_{t r}=H_{t r, a d j}\left(\theta_{\text {int.set }}-\theta_{e}\right) t
$$

The convective heat loss coefficient $H_{t r, a d j}$ was calculated for all structural partitions with the use of the following formula:

$$
H_{t r}=\sum_{x}\left[b_{t r, x}\left(\sum_{i} A_{i} U_{i}+\sum_{k} l_{k} \Psi_{k}+\sum_{j} \chi_{j}\right)\right]
$$

The following equation was applied to calculate ventilation heat transfer in the building:

$$
Q_{v e}=H_{v e, a d j}\left(\theta_{\text {int.set }}-\theta_{e}\right) t
$$


The ventilation heat loss coefficient $H_{v e, a d j}$ was determined with the use of the following formula:

$$
H_{v e}=\rho_{a} c_{a}\left(\sum_{k} b_{v e, k} q_{v e, k, m n}\right)
$$

Total radiant heat gain in the building was calculated as follows:

$$
Q_{s o l}=\left[\sum_{k} \Phi_{s o l, k}+\sum_{l}\left(1-b_{t r, l}\right) \Phi_{s o l, u, l}\right] t
$$

The following equations were applied to calculate radiant heat gain:

$$
\begin{gathered}
\Phi_{s o l, k}=F_{s h, o b, k} A_{s o l, k} I_{s o l, k}-F_{r, k} \Phi_{r, k} \\
A_{s o l, k}=F_{s h, g l, k} g_{g l, k}\left(1-F_{F, k}\right) A_{w, p} \\
\Phi_{r, k}=R_{s e} U_{C} A_{C} h_{r} \Delta \theta_{e r} \\
h_{r}=4 \varepsilon \sigma\left(Q_{s s}+273\right)^{3}
\end{gathered}
$$

Motorized exterior solar shades were incorporated into one of the analyzed scenarios. The shades are controlled by a solar radiation sensor, and they can block up to $85 \%$ of solar radiation. The shades are automatically closed when solar radiation exceeds $800 \mathrm{~W} / \mathrm{m}^{2}$.

The heating and cooling capacity of the GAHE was calculated with the following formula [58]:

$$
Q_{G A H E}=\dot{m} c_{p}\left(\theta_{e}-\theta_{I n}\right) t
$$

A positive result indicates that heat was transferred from ground to air, whereas a negative result indicates that air was cooled in the GAHE. Heating and cooling loads were determined on an hourly basis, and the results were expressed in Wh.

In variants 3 and 4 , where a HE was incorporated into the mechanical ventilation system, the efficiency of heat recovery was determined at $90 \%$ with the use of Formula (14). Counterflow HEs are characterized by similar heat recovery efficiency:

$$
\eta_{H E \text { vent }}=\frac{\theta_{\text {sup }, k}-\theta_{e}}{\theta_{\text {int }, \text { set }}-\theta_{e}}
$$

If the temperature of outdoor air was above $0{ }^{\circ} \mathrm{C}$, the amount of heat recovered by the HE was calculated with the use of Formula (15):

$$
Q_{H E}=H_{v e, a d j}\left(\theta_{e}-\theta_{\text {sup }, k}\right) t
$$

If the temperature of outdoor air was below $0{ }^{\circ} \mathrm{C}$, the air was heated to $0{ }^{\circ} \mathrm{C}$ by a $\mathrm{PH}$. The energy consumption of the PH was determined with the use of Formula (16):

$$
Q_{P H}=H_{v e, a d j}\left(\theta_{0}-\theta_{e}\right) t
$$

Formula (17) was applied to calculate the amount of heat recovered in variant 4 , where outdoor air passed through the GAHE before reaching the HE:

$$
Q_{H E_{G A H E}}=H_{v e, a d j}\left(\theta_{\text {in }}-\theta_{\text {sup }, k}\right) t
$$

In some cases, air that is preconditioned in the $\mathrm{HE}$ is additionally heated to a temperature of $20^{\circ} \mathrm{C}$ with the use of an $\mathrm{SH}$. The energy consumption of the $\mathrm{SH}$ was calculated with the use of Formula (18):

$$
Q_{S H}=H_{v e, a d j}\left(\theta_{20}-\theta_{i n t, C, s e t}\right)
$$


Latent heat transfer, namely the energy released during water vapor condensation, was determined with the use of Formula (19) at hourly intervals [59]. The results were expressed in Wh.

$$
Q_{t}=\dot{m} \cdot\left(h_{e}-h_{I n}\right)
$$

Air enthalpy was calculated with the below formula:

$$
h=c_{d} T+\left(q+c_{v} T\right) d
$$

\section{Results}

Typical Meteorological Year (TMY) data were compared with the results of the measurements conducted during the three-year experiment. The average hourly outdoor temperature was $6.9^{\circ} \mathrm{C}$ in the TMY dataset, and it was determined at $9.3^{\circ} \mathrm{C}$ in $2017,11.7^{\circ} \mathrm{C}$ in 2018 , and $10.1^{\circ} \mathrm{C}$ in 2019 . In the TMY, annual temperatures ranged from $-17.3^{\circ} \mathrm{C}$ to $31.0^{\circ} \mathrm{C}$, whereas the temperature range in each year of the experiment was determined at $-17.4{ }^{\circ} \mathrm{C}$ to $29.0^{\circ} \mathrm{C}$ in $2017,-16.2{ }^{\circ} \mathrm{C}$ to $31.5^{\circ} \mathrm{C}$ in 2018 , and $-10.9^{\circ} \mathrm{C}$ to $33.2^{\circ} \mathrm{C}$ in 2019 (Figure 2).

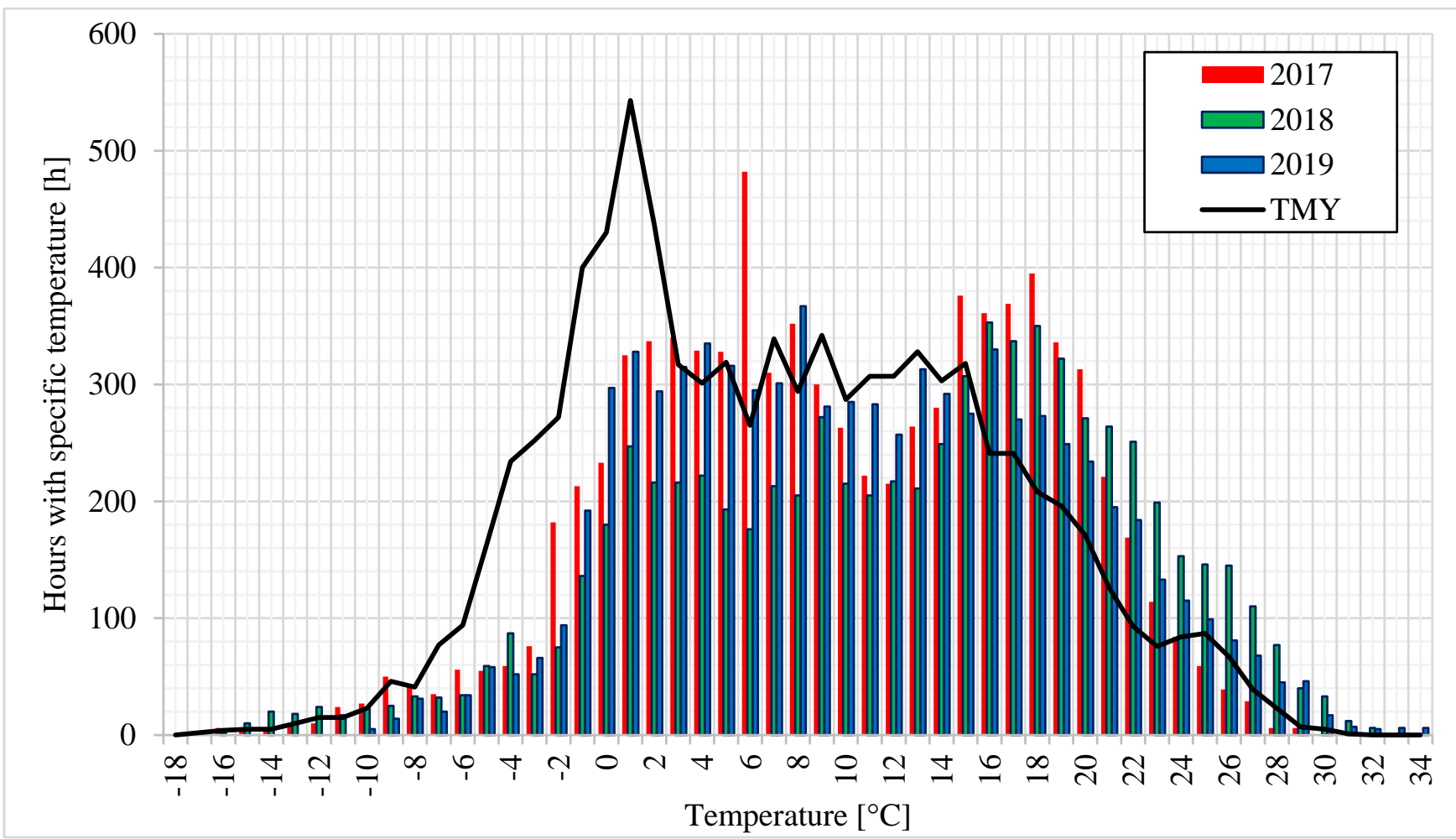

Figure 2. Outdoor temperature histogram.

The most frequently noted average hourly ambient temperature was $1{ }^{\circ} \mathrm{C}$ in the TMY dataset, and in the three-year experiment: $5.3^{\circ} \mathrm{C}$ in $2017,6.7^{\circ} \mathrm{C}$ in 2018 , and $4.5^{\circ} \mathrm{C}$ in 2019 . The number of hours with a temperature range of $-7^{\circ} \mathrm{C}$ to $2^{\circ} \mathrm{C}$ was much higher in the TMY than in the experimental years (approx. twice higher on average, up to five times in extreme cases). In turn, the number of hours characterized by a temperature range of $16{ }^{\circ} \mathrm{C}$ to $23{ }^{\circ} \mathrm{C}$ was considerably higher during the experiment than in the TMY dataset. The TMY dataset was most highly correlated with the data measured in $2019(r=0.87)$ and least correlated with the data measured in $2018(r=0.69)$.

The average hourly solar irradiance was $104.6 \mathrm{~W} / \mathrm{m}^{2}$ in the TMY, whereas during the experiment, this parameter was determined at $114.1 \mathrm{~W} / \mathrm{m}^{2}$ in $2017,143.3 \mathrm{~W} / \mathrm{m}^{2}$ in 2018 , and $126.8 \mathrm{~W} / \mathrm{m}^{2}$ in 2019 . The number of hours with average solar irradiance of $50-600 \mathrm{~W} / \mathrm{m}^{2}$ was much higher in the TMY dataset than in the set of measured values. However, the 
experimental dataset was characterized by a higher number of hours with average solar irradiance above $700 \mathrm{~W} / \mathrm{m}^{2}$. For example, the number of hours with solar irradiance above $1000 \mathrm{~W} / \mathrm{m}^{2}$ was determined at 5 in the TMY dataset, and it was considerably higher in the experimental dataset at 85 in 2017, 46 in 2018, and 39 in 2019.

An analysis of temperature distribution at the GAHE outlet (Figure 3) clearly indicates that outdoor air was both preheated and precooled in the GAHE. The average temperature threshold for preheating and precooling was around $19.2^{\circ} \mathrm{C}$ in 2017 , around $20.3^{\circ} \mathrm{C}$ in 2018 , and around $21.1^{\circ} \mathrm{C}$ in 2019 . Air was preheated if ambient temperatures were below the above threshold values, and it was precooled when ambient temperatures exceeded these values. In winter, the air required more warming as outdoor temperatures decreased. Subzero temperatures were never recorded at the GAHE outlet. In summer, the air had to be progressively cooled as ambient temperatures increased. In 2017, the average temperature at the GAHE outlet reached $13.0^{\circ} \mathrm{C}$, and it ranged from $2.8^{\circ} \mathrm{C}$ to $22.9^{\circ} \mathrm{C}$. In 2018 , the average temperature at the GAHE outlet was determined at $14.8^{\circ} \mathrm{C}$, in the range of $4.0^{\circ} \mathrm{C}$ to $24.8^{\circ} \mathrm{C}$. In 2019 , the average temperature at the GAHE outlet reached $13.6^{\circ} \mathrm{C}$, and it ranged from $4.4{ }^{\circ} \mathrm{C}$ to $25.3^{\circ} \mathrm{C}$. The average increase in the temperature of outdoor air preheated in the GAHE was $5.9^{\circ} \mathrm{C}$ in $2017,4.0^{\circ} \mathrm{C}$ in 2018 , and $4.6^{\circ} \mathrm{C}$ in 2019 . In turn, the temperature of outdoor air precooled in the GAHE decreased by $1.6^{\circ} \mathrm{C}$ in $2017,2.2^{\circ} \mathrm{C}$ in 2018 , and $2.6^{\circ} \mathrm{C}$ in 2019 on average.

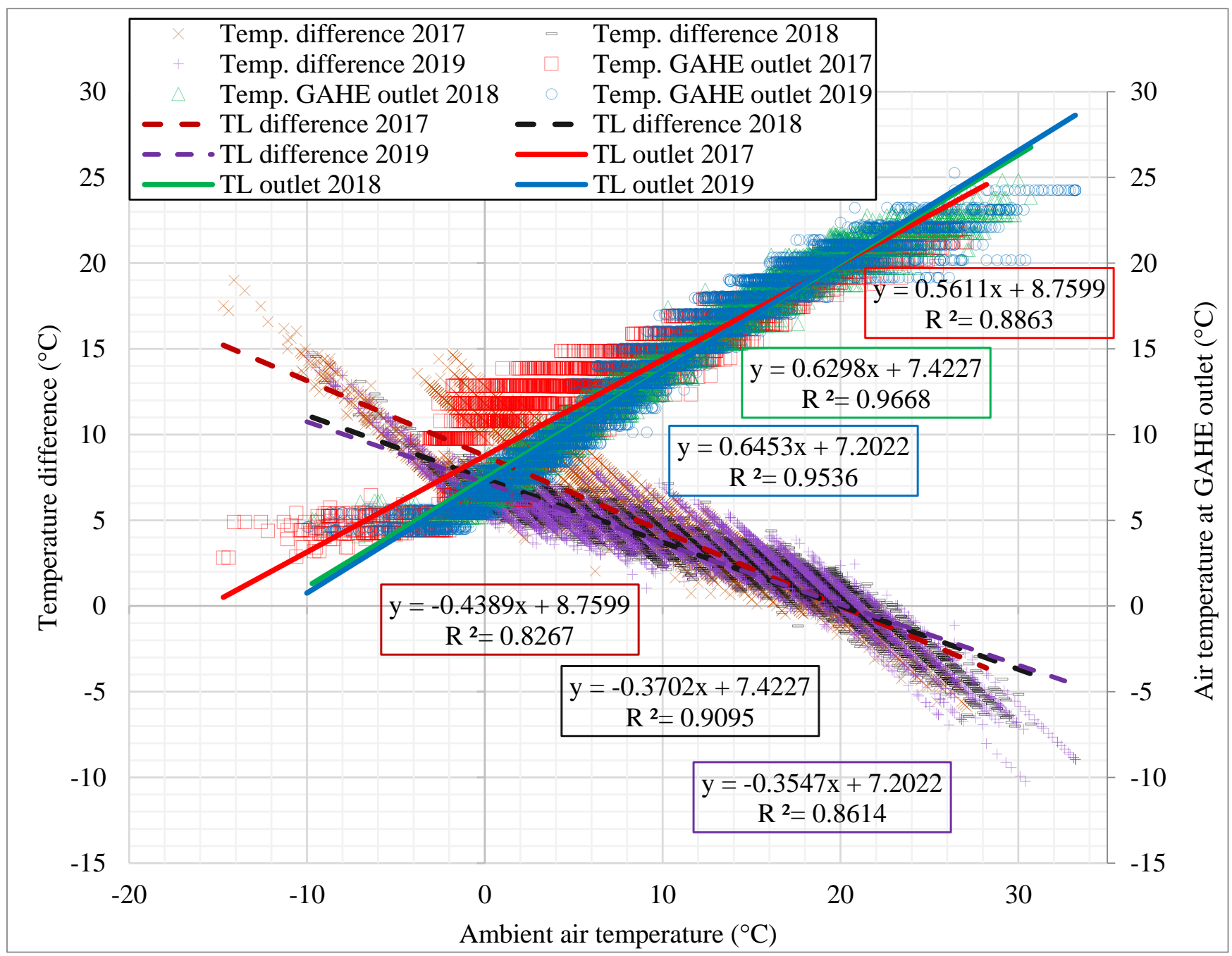

Figure 3. Temperature distribution at the GAHE outlet and difference between the temperature at the GAHE outlet and ambient temperature. 
Convective heat transfer $Q_{t r}$, radiant heat gain $Q_{s o l}$, and ventilation heat transfer $Q_{v e}$ were taken into account in the building's overall energy balance. The first two factors $\left(Q_{t r}\right.$ and $Q_{s o l}$ ) determine the building's heating or cooling load $Q_{B}$. Internal heat gain $Q_{i n t}$ was not considered in the analysis because it remains constant throughout the year and is not influenced by weather (Figure 4).

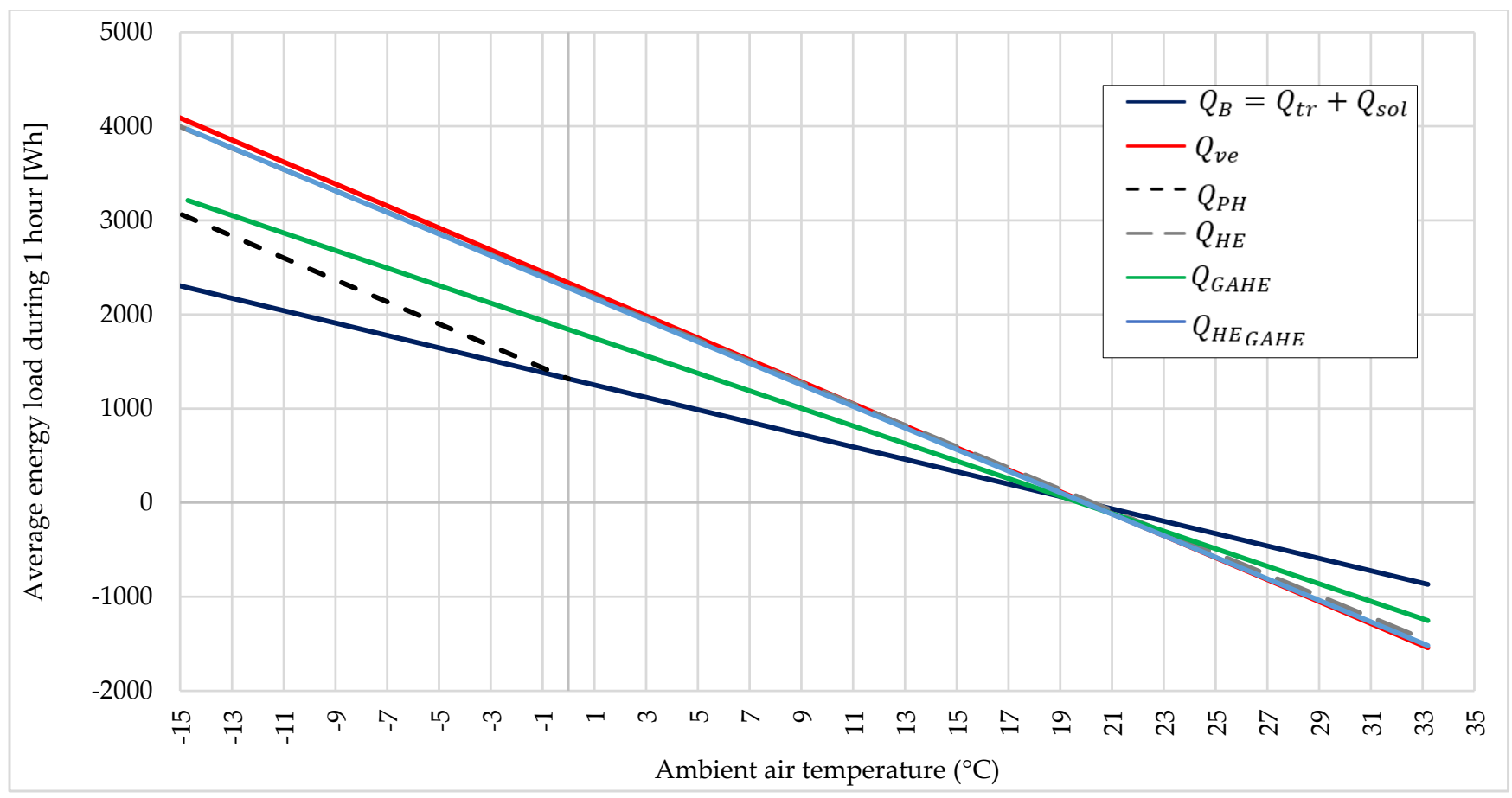

Figure 4. Boundary values of hourly energy loads [Wh] in the entire building at different ambient temperatures-maximum heating energy load and minimum cooling energy load in all systems.

In variant 1 (Figure 4), where the supplied outdoor air was not preconditioned, around half of the heat demand was generated by ventilation. Between April and September, radiant heat gain from transparent partitions was responsible for most of the cooling load. Ventilation cooling capacity accounted for only $2.9 \%$ of the building's total cooling load. In variant 2 (Figure 4), fresh outdoor air passed through the GAHE before it entered the building, and preconditioned air supplied around $55 \%$ of the heat to the ventilation system in summer and around $40 \%$ of heat in the remaining seasons of the year. The heat removed from ventilation air by the GAHE accounted for only $2.9 \%$ of the building's total cooling load in summer. However, in some hours, the cooling capacity of the GAHE accounted for nearly $30 \%$ of the overall cooling load. The above was observed when the high ambient temperature was not accompanied by radiant heat gain. Nonetheless, the cooling capacity of the GAHE accounted for around $73 \%$ of the ventilation cooling load in summer (Figure 5). The energy loads presented in Figure 5 were determined separately for heating and cooling energy in each device in the analyzed HVAC variants. These values were presented separately for each month of the year. The energy load for a given month was expressed by the arithmetic mean of the energy loads for the corresponding months of 2017, 2018, and 2019. 


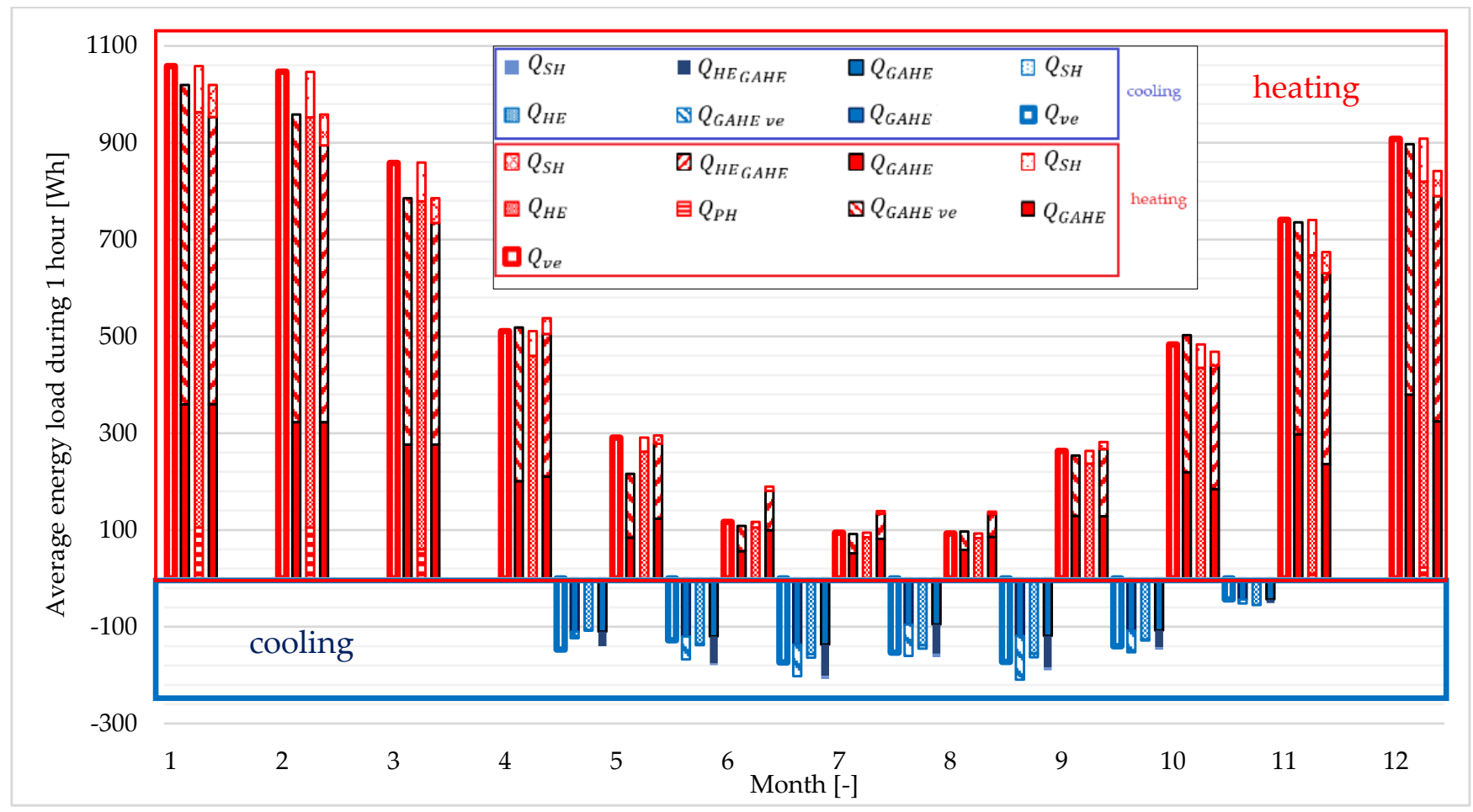

Figure 5. Average hourly energy load [Wh] in the ventilation system. In each month, variants 1, 2, 3, and 4 are represented by the respective bars in each group of four bars.

In variant 3, a PH was used to prevent the $\mathrm{HE}$ from freezing. When the ambient temperature dropped below $0{ }^{\circ} \mathrm{C}$, the $\mathrm{PH}$ warmed the supplied air to $0{ }^{\circ} \mathrm{C}$. The $\mathrm{PH}$ was operated between November and April. In January and February, which are the coldest months of the year, the heating capacity of the $\mathrm{PH}$ accounted for around $10 \%$ of the total heating load in the ventilation system. During the three-year experiment, the $\mathrm{PH}$ was responsible for $5 \%$ of ventilation heat demand on average. The energy demand of the $\mathrm{PH}$ increased with a decrease in ambient temperature (Figure 4). At extremely low outdoor temperatures, the heat demand of the $\mathrm{PH}$ accounted for $45 \%$ of the building's energy load. A ventilation system with heat recovery effectively removed heat from exhaust air. In winter, the temperature at the GAHE outlet did not decrease below $18{ }^{\circ} \mathrm{C}$ and was determined at $19^{\circ} \mathrm{C}$ on average. The temperature of the air flowing into the $\mathrm{HE}$ was raised by around $10{ }^{\circ} \mathrm{C}$ on average, and the maximum increase was $18{ }^{\circ} \mathrm{C}$. When air-conditioning was incorporated into the modeled system, the temperature at the HE outlet was maintained at around $21^{\circ} \mathrm{C}$. In summer, the temperature of the air flowing into the $\mathrm{HE}$ was decreased by around $3{ }^{\circ} \mathrm{C}$ on average, and the maximum decrease was $12{ }^{\circ} \mathrm{C}$. Heat recovery from the HE accounted for around $87 \%$ of the annual heating load, and it was somewhat lower (approx. 84\%) in the winter. The $\mathrm{SH}$ was responsible for around $9 \%$ of the demand for heat in the ventilation system. When air-conditioning was incorporated into the model, the heat recovered by the HE was responsible for around $90 \%$ of the demand for cooling energy in the ventilation system (Figure 5).

In variant 4 (identical to variant 3 , but with the addition of the GAHE), no significant differences in temperature at the $\mathrm{HE}$ outlet were observed relative to variant 3 . In variant 4 , the average temperature at the $\mathrm{HE}$ outlet was determined at $19.3^{\circ} \mathrm{C}$. The need for the $\mathrm{PH}$ was completely eliminated when the GAHE was incorporated into the system. On average, air preheating in the GAHE covered the demand for heat by $44 \%$ and the demand for cooling energy by $67 \%$ in the ventilation system (Figure 5). The HE covered the demand for heat by around $50 \%$ and the demand for cooling energy by $30 \%$ in the ventilation system. Air preheating to a temperature of $20^{\circ} \mathrm{C}$ in the $\mathrm{HE}$ was responsible for around $6 \%$ of the heating load and around 3\% of the cooling load in the building's overall energy balance. 
An analysis of average hourly energy loads per $1 \mathrm{~m}^{2}$ of floor area in different months of the year (Table 1) indicates that the building should be cooled between April and September and heated in the remaining months of the year to guarantee maximum thermal comfort. The demand for cooling energy is highest in May, June, July, and August, whereas the demand for heat is highest in January, February, and December. Cooling energy was generated mainly by heat transfer through the building's walls and roof, in particular radiant heat gain through transparent partitions. To guarantee a stable indoor temperature of $20^{\circ} \mathrm{C}$, outdoor air has to be mainly heated before it enters the building, including in the summer months, because ambient temperatures were below $20{ }^{\circ} \mathrm{C}$ in around $50 \%$ of the hours analyzed between June and August. Even in hot months (such as August 2018 when the outdoor temperature exceeded $31^{\circ} \mathrm{C}$ ), much lower minimum temperatures were also recorded $\left(8.5^{\circ} \mathrm{C}\right)$, and even if the average monthly temperature reached $20.2^{\circ} \mathrm{C}$, the monthly median temperature was only $19^{\circ} \mathrm{C}$. Outdoor air had to be preheated during around $83 \%$ of the hours in April, May, and September.

Table 1. Average hourly energy loads per $1 \mathrm{~m}^{2}$ of floor area $\left[\mathrm{Wh} / \mathrm{m}^{2}\right]$

\begin{tabular}{|c|c|c|c|c|c|c|c|c|c|c|}
\hline \multirow{3}{*}{ Month } & \multirow{3}{*}{$\begin{array}{c}Q_{B}=Q_{t r}+Q_{s o l} \\
\quad\left[\mathrm{Wh} / \mathrm{m}^{2}\right]\end{array}$} & \multicolumn{9}{|c|}{ Average Hourly Energy Demand in the Ventilation System $\left[\mathrm{Wh} / \mathrm{m}^{2}\right]$} \\
\hline & & \multirow{2}{*}{$\begin{array}{c}\text { Variant } 1 \\
Q_{v e}\end{array}$} & \multicolumn{2}{|c|}{ Variant 2} & \multicolumn{3}{|c|}{ Variant 3} & \multicolumn{3}{|c|}{ Variant 4} \\
\hline & & & $Q_{G A H E}$ & $Q_{v e}$ & $Q_{P H}$ & $Q_{H E}$ & $Q_{S H}$ & $Q_{G A H E}$ & $Q_{H E}$ & $Q_{S H}$ \\
\hline Jan & 10.46 & 9.19 & 3.12 & 5.73 & 0.91 & 7.45 & 0.83 & 3.13 & 5.16 & 0.58 \\
\hline Feb & 9.07 & 9.09 & 2.80 & 5.52 & 0.91 & 7.35 & 0.82 & 2.80 & 4.97 & 0.55 \\
\hline Mar & 5.68 & 7.45 & 2.40 & 4.42 & 0.52 & 6.24 & 0.69 & 2.43 & 3.98 & 0.44 \\
\hline Apr & -1.28 & 4.38 & 1.70 & 2.75 & 0.00 & 3.94 & 0.44 & 1.70 & 2.48 & 0.28 \\
\hline May & -4.46 & 2.31 & 0.48 & 1.05 & 0.00 & 2.08 & 0.23 & 0.45 & 0.98 & 0.12 \\
\hline June & -8.41 & 0.37 & 0.03 & 0.25 & 0.00 & 0.34 & 0.04 & 0.03 & 0.18 & 0.05 \\
\hline July & -7.76 & 0.21 & 0.13 & 0.12 & 0.00 & 0.19 & 0.02 & 0.13 & 0.04 & 0.03 \\
\hline Aug & -6.99 & 0.14 & 0.14 & 0.05 & 0.00 & 0.13 & 0.01 & 0.13 & 0.00 & 0.03 \\
\hline Sept & -2.66 & 2.12 & 1.01 & 1.04 & 0.00 & 1.91 & 0.21 & 1.03 & 0.93 & 0.11 \\
\hline Oct & 1.78 & 4.20 & 1.90 & 2.46 & 0.00 & 3.78 & 0.42 & 1.90 & 2.22 & 0.25 \\
\hline Nov & 6.97 & 6.43 & 2.59 & 3.80 & 0.08 & 5.71 & 0.63 & 2.60 & 3.42 & 0.38 \\
\hline Dec & 9.17 & 7.88 & 3.30 & 4.49 & 0.19 & 6.93 & 0.77 & 3.30 & 4.04 & 0.45 \\
\hline
\end{tabular}

\section{Discussion}

The TMY is a specific set of statistical data which, in the analyzed case, was based on meteorological data measured between 1970 and 2000. Historical statistical data diverged considerably from the real-world parameters measured between 2017 and 2019. The measurements conducted over a period of three years do not support reliable long-term climate predictions. However, the measured data are consistent with the trends described in a 2020 report of the Institute of Meteorology and Water Economy [60] which states that the average annual temperature in Poland increased by $1.6^{\circ} \mathrm{C}$ between 2020 and TMY data. In this study, the increase in average annual temperature relative to TMY data was even more pronounced, and it was determined at $3.47^{\circ} \mathrm{C}$. However, the measured data were incomplete, which could have undermined the reliability of the results. Data were acquired for $95 \%$ of the hours measured in $2017,83 \%$ of the hours measured in 2018 , and $89 \%$ of the hours measured in 2019.

It should also be noted that the GAHE did not operate continuously in all years of the experiment. The temperature at the GAHE outlet was determined during $67 \%$ of the hourly measurements conducted in 2017, 51\% of the hourly measurements conducted in 2018, and $64 \%$ of the hourly measurements conducted in 2019. Periodic downtimes, including at night when the GAHE operates in cooling mode, are scheduled to regenerate the ground source, reduce energy consumption in the ventilation system, minimize flow resistance in the GAHE, and improve thermal comfort by relying on low nocturnal temperatures. An analysis of the parameters measured at the GAHE outlet clearly indicates that the examined solution was effective both in heating and cooling mode. A GAHE also contributes to sus- 
tainable construction by improving a building's climate adaptability, including resilience to daily weather as well as global climate change [61]. The daily sum of absolute temperature differences in successive hours (Figure 6) clearly indicates that the daily sum of temperature increases at the GAHE outlet was nearly $48 \%$ lower relative to ambient air. Moreover, daily changes in temperature at the GAHE outlet were not observed in $5 \%$ to $10 \%$ of the cases in the analyzed period. In contrast, daily changes in ambient temperature were observed in all cases throughout the entire three-year experiment.

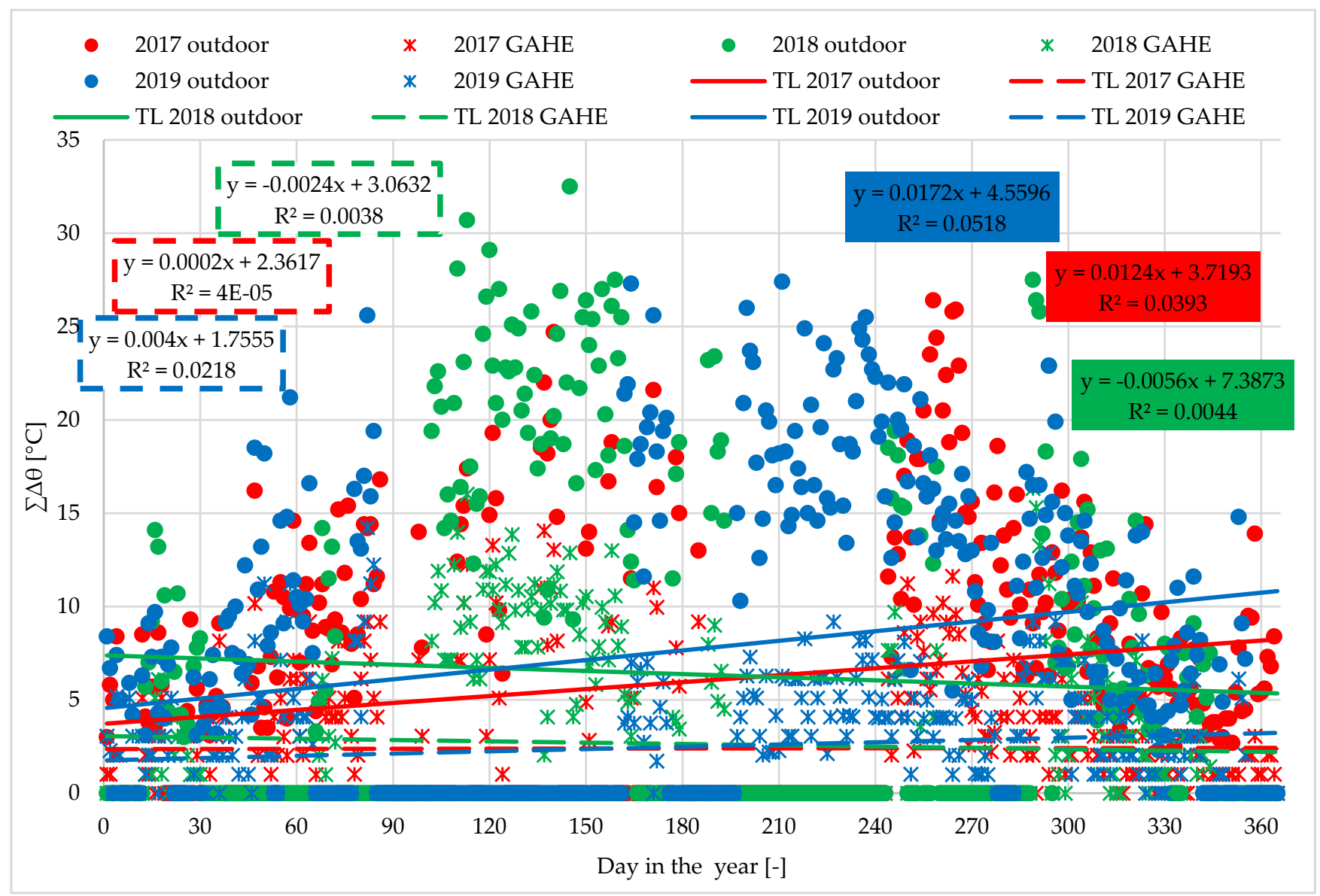

Figure 6. Daily sum of absolute changes in ambient temperature and temperature at the GAHE outlet between two consecutive hours.

The heat demand of the ventilation system accounted for around 50\% of the overall heating load in the building. The modeled building is a modern structure with high envelope airtightness and well-insulated structural partitions. Radiant heat gain from glazed partitions significantly influenced the building's cooling load. Motorized exterior solar shades controlled by a solar radiation sensor were incorporated into the analyzed scenario to prevent overheating due to radiant heat gain. This solution decreased the building's cooling load by around $25 \%$ relative to the variant without solar shades. To supply air with a constant temperature of $20^{\circ} \mathrm{C}$, incoming air had to be heated during the entire year, and it had to be cooled or heated between April and October, depending on weather conditions. However, fresh air is not preheated in buildings with natural ventilation, and the amount of heat that is required to ensure thermal comfort (and compensate for convective and ventilation heat loss) is generated by the heating system. Typical heating solutions include hot water radiators or underfloor heating systems. These systems generate heat in cold seasons of the year when the building has to be heated rather than cooled. However, air conditioning is required to ensure thermal comfort in summer. Air conditioning is not a standard feature in Polish homes. In modern airtight and well-insulated buildings, 
temperatures exceeding human comfort levels are noted in summer [62]. Overheating is a problem that persists throughout the year [63]. Ground-to-air heat exchangers can reduce the heat demand of the ventilation system by around 50\%. Between April and October, a GAHE generates approximately $75 \%$ of the cooling energy for the ventilation system. In winter, a GAHE caters to around $19 \%$ of the total heat demand in the building. A GAHE generates around $3 \%$ of the overall cooling energy. It should also be noted that ambient air is generally not preheated in summer. During long summer days, radiant heat gain significantly exceeds the cooling energy supplied with outdoor air. Heat accumulation in transparent partitions also contributes to thermal comfort in periods when ambient temperatures are low. When the supplied air was not preheated between May and August, the annual heat demand of the ventilation system was reduced by around $10 \%$ in variant 1. However, in June, July, and August, the average hourly temperature of the supplied air decreased below $10^{\circ} \mathrm{C}$ in some cases (the lowest recorded temperature was $7.1^{\circ} \mathrm{C}$ ). The situation was most problematic in May when nocturnal temperatures dropped below $0{ }^{\circ} \mathrm{C}$ in extreme cases, and when the minimum average hourly temperature was as low as $-0.5^{\circ} \mathrm{C}$. In such cases, building users make individual decisions regarding thermal comfort. Indoor thermal comfort is influenced by parameters that were not evaluated in this study, including heat accumulation in structural partitions and indoor heat gain. The decision to turn on the heat during short cold spells will depend on the heating source (district vs. individual heating) and the ease of regulating the heating system. In variant 2 , the heat demand of the ventilation system was reduced by around $5 \%$ when outdoor air was not preheated. The GAHE significantly improved indoor thermal comfort and decreased the number of hours when the temperature of supplied air was below $20^{\circ} \mathrm{C}$. The temperature of ventilation air also increased, and the resulting difference was most noticeable during short spells of cold weather (such as nocturnal frost in May). In May, the lowest temperature recorded at the GAHE outlet was around $9{ }^{\circ} \mathrm{C}$.

The total heating and cooling energy generated by the GAHE was also analyzed (Figure 5). On average, the GAHE supplied $1194.5 \mathrm{kWh}$ of heat energy during the year, and $1023.0 \mathrm{kWh}$ of heat energy between October and April during each year of the study. The analyzed device-generated $66.2 \mathrm{kWh}$ of cooling energy each year. However, it should be noted that the GAHE operated in heating mode for around $90 \%$ of the registered hours (4638 h) and in cooling mode for only around 10\% of the registered hours (531 h). Therefore, the device generated around $257.6 \mathrm{~W}$ of heating energy per hour in heating mode and around $124.7 \mathrm{~W}$ of cooling energy per hour in cooling mode (during the year). Such high differences in the duration of heating and cooling modes can be attributed to the characteristics of the studied site rather than climate. The analyzed GAHE operates on the campus of the University of Warmia and Mazury in Olsztyn. If unplanned downtime is disregarded, maintenance breaks are usually scheduled during the summer when student dormitories are not occupied. Only some academic personnel work in the University's buildings during the summer holiday. As a result, the demand for ventilation air is decreased and internal heat gain from building occupants is reduced. The building is adequately ventilated at night, and the GAHE is periodically turned off to save energy.

In this study, the extent to which a HE can improve the energy balance of a singlefamily home was analyzed based on the experimentally determined temperature of fresh air supplied to the HE, the desired indoor temperature, and the average heat recovery efficiency of a HE, which was determined upon consultation with the leading producers of ventilation systems in Poland. This experiment was conducted on the assumption that the heat recovery efficiency of the HE was constant, which is a considerable oversimplification of a complex problem. However, this problem cannot be analyzed in detail in this study because the performance of the $\mathrm{HE}$ was not monitored continuously during the experiment. In real-world conditions, heat recovery efficiency generally decreases with a rise in ambient temperature [64]. The heat recovery efficiency of a HE can be compromised when a GAHE is incorporated into the system. 
The heating energy load is unlikely to be higher than that described in the energy balance. Higher demand for heat could occur only in periods of very cold weather. However, the cooling energy load could increase if additional heat gains (that were not considered in the energy balance) occur. The boundary values of the energy load, including the maximum energy load for heating purposes and the minimum energy load for cooling purposes, in each analyzed HVAC variant are presented in Figure 4. When the GAHE is operating in both heating and cooling mode, higher solar heat gain can decrease the demand for heating energy or increase the demand for cooling energy. Internal heat gains from building occupants, lamps, and electrical equipment will have similar consequences, but they were not considered in the overall energy balance.

It should also be noted that latent heating and cooling loads are not considered in standard ISO 13790:2008. However, research has demonstrated that latent heating and cooling loads considerably affect the overall energy balance $[65,66]$. In the present study, the GAHE was characterized by similar sensible and latent effectiveness of heat recovery in summer (Table 2). In winter, sensible heat recovery was around $12 \%$ higher than latent heat recovery. In summer, latent heat recovery was around $25 \%$ higher than sensible heat recovery.

Table 2. Sensible and latent heat recovery in the GAHE under heating and cooling conditionsaverage hourly energy load per $1 \mathrm{~m}^{2}$ of usable floor area $\left[\mathrm{Wh} / \mathrm{m}^{2}\right]$.

\begin{tabular}{ccccc}
\hline & \multicolumn{3}{c}{ Average Hourly Energy Demand in the Ventilation System $\left[\mathrm{Wh} / \mathbf{m}^{2}\right]$} \\
\cline { 2 - 5 } Month & \multicolumn{2}{c}{ Heating Load } & \multicolumn{2}{c}{ Cooling Load } \\
\cline { 2 - 5 } & $\begin{array}{c}\text { Sensible } \\
\text { Heat }\end{array}$ & $\begin{array}{c}\text { Latent } \\
\text { Heat }\end{array}$ & $\begin{array}{c}\text { Sensible } \\
\text { Heat }\end{array}$ & $\begin{array}{c}\text { Latent } \\
\text { Heat }\end{array}$ \\
\hline Jan & 3.12 & 2.94 & 0.00 & 0.00 \\
Feb & 2.80 & 2.39 & 0.00 & 0.00 \\
Mar & 2.40 & 2.36 & 0.00 & 0.00 \\
Apr & 1.74 & 1.27 & -0.04 & -0.08 \\
May & 0.73 & 0.73 & -0.25 & -0.31 \\
June & 0.49 & 0.50 & -0.46 & -0.61 \\
July & 0.45 & 0.45 & -0.32 & -0.43 \\
Aug & 0.51 & 0.59 & -0.37 & -0.39 \\
Sept & 1.12 & 1.17 & -0.11 & -0.10 \\
Oct & 1.90 & 1.79 & 0.00 & 0.00 \\
Nov & 2.59 & 2.28 & 0.00 & 0.00 \\
Dec & 3.30 & 2.63 & 0.00 & 0.00 \\
\hline
\end{tabular}

\section{Conclusions}

The observations conducted in this experiment support the global consensus on climate change. The heating capacity of a GAHE can be overestimated, whereas its cooling capacity can be underestimated when the model's performance is evaluated based on a TMY dataset that aggregates historical measurements. The resulting inaccuracies can affect engineering solutions, such as the length and diameter of GAHE pipes. These problems indicate that meteorological data and weather models, such as the TMY dataset, should be regularly updated.

During the heating season, the maximum increase in temperature at the GAHE outlet reached $19.0^{\circ} \mathrm{C}$ in $2017,14.8^{\circ} \mathrm{C}$ in 2018 , and $14.6^{\circ} \mathrm{C}$ in 2019 . In summer, the maximum decrease in temperature at the GAHE outlet was determined at $-5.9^{\circ} \mathrm{C},-7.0^{\circ} \mathrm{C}$, and $-10.2{ }^{\circ} \mathrm{C}$, respectively. During the three-year study, the temperature at the GAHE outlet increased by $5.8^{\circ} \mathrm{C}$ on average, whereas the average decrease in temperature at the GAHE outlet in summer reached $-2.4^{\circ} \mathrm{C}$. The GAHE generated $3583.4 \mathrm{kWh}$ of heating energy during the entire three-year study, including $3069.0 \mathrm{kWh}$ during the heating season (October to April). The analyzed device supplied $198.6 \mathrm{kWh}$ of cooling energy between 2017 and 
2019. During the heating season, the GAHE generated $307.2 \mathrm{~W}$ of heating energy per hour and $124.7 \mathrm{~W}$ of cooling energy per hour.

A GAHE can considerably reduce energy consumption in ventilation systems. The results of a three-year experiment conducted in Poland revealed that a GAHE is particularly effective in preheating outdoor air that is supplied to the ventilation system in winter. A GAHE reduces the demand for energy in the ventilation system by around $45 \%$, and it can reduce the energy load of the entire building by around $20 \%$. In summer, a GAHE supplies around $75 \%$ of the energy for cooling ventilation air. However, the generated energy accounts for only around 3\% of the overall energy load in modern buildings that are airtight, well insulated, and feature large glazed partitions. Glazed partitions are the main source of radiant heat transfer; therefore, solar shades should be applied to prevent the building from overheating in summer. In buildings where the ventilation system is coupled with a GAHE, thermal comfort can be maximized by installing air-conditioning.

A GAHE also improves energy efficiency in buildings that are equipped with mechanical ventilation systems with heat recovery and a HE. In this scenario, a PH that protects the system from freezing can be completely eliminated, and heat can be recovered continuously by the HE without bypass solutions.

The study demonstrated that the amount of latent heat that is captured and dissipated by a GAHE significantly affects the building's overall energy balance. This observation should be taken into account in the design and engineering methods for calculating a building's energy load.

A GAHE is also a solution that deserves special attention in the context of sustainability. In an era of rapid climate change, a GAHE effectively reduces the energy demand of ventilation systems under highly variable weather conditions. As a result, a GAHE significantly contributes to the development of sustainable buildings that are resilient to climate change.

According to the Köppen classification, Poland belongs to the humid continental climatic region. The results of the present experiment were obtained under local conditions, but they characterize the performance of a GAHE in the entire climatic zone. These observations also constitute valuable reference data for studies conducted in other locations.

The real-world performance of a GAHE was analyzed in the climate of Central-Eastern Europe and in various configurations of the HVAC system in a single-family home. The results can be used to select the optimal heating and ventilation scenarios for engineering projects as well as private home construction projects. Four popular HVAC scenarios were analyzed in this study, but other configurations are also possible. Further research is needed to address rapid technological progress, climate change, and more stringent energy-efficiency standards in the construction industry.

Funding: This research received no external funding.

Institutional Review Board Statement: Not applicable.

Informed Consent Statement: Not applicable.

Data Availability Statement: Data available on request due to restrictions eg privacy or ethical.

Conflicts of Interest: The authors declare no conflict of interest. 


\section{Abbreviations}

$A_{c} \quad$ projected area of the element $\left[\mathrm{m}^{2}\right]$

$A_{i} \quad$ area of element i $\left[\mathrm{m}^{2}\right]$

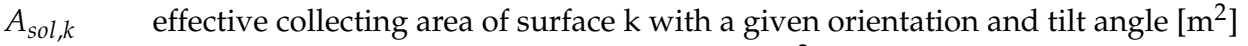

$A_{w, p}$

$b_{t r, l}$

overall projected area of the glazed element $\left[\mathrm{m}^{2}\right]$

$b_{t r, x} \quad$ adjustment factor

$b_{v e, k} \quad$ temperature adjustment factor for airflow

$c_{d} \quad$ average specific heat of dry air at constant pressure; $1001[\mathrm{~J} /(\mathrm{kg} \mathrm{K})]$

$c_{v} \quad$ average specific heat of water vapor at constant pressure; 1840 [J/(kg K)]

$d \quad$ specific humidity $[\mathrm{kg} / \mathrm{kg}]$

$F_{F} \quad$ frame area fraction, ratio of the projected frame area to the overall projected area of the glazed element

$F_{r, k} \quad$ form factor between the building element and the sky

$F_{s h, g l} \quad$ shading reduction factor for movable shading provisions

$F_{s h, o b, k} \quad$ shading reduction factor for external obstacles for the solar collective area of surface $\mathrm{k}$

$g_{g l}$

$h_{\text {In }}$

$h_{e}$

$h_{r}$

$H_{t r, a d j}$

$H_{\text {ve, adj }}$

total solar energy transmittance of the transparent part of the element

enthalpy of fresh air at the GAHE inlet [J/ kg]

enthalpy of fresh air at the GAHE outlet [J/kg]

external radiative heat transfer coefficient $\left[\mathrm{W} / \mathrm{m}^{2} \mathrm{~K}\right]$

overall heat transfer coefficient $[\mathrm{W} / \mathrm{K}]$

overall ventilation heat transfer coefficient $[\mathrm{W} / \mathrm{K}]$

$I_{\text {sol,k }}$

solar irradiance, mean solar irradiation energy during the time step of the calculation,

$l_{k} \quad$ length of linear thermal bridge $\mathrm{k}[\mathrm{m}]$ per square meter of collecting area of Surface $\mathrm{k}\left[\mathrm{W} / \mathrm{m}^{2}\right]$

$\dot{m} \quad$ mass air flow rate $[\mathrm{kg} / \mathrm{s}]$

$q \quad$ vaporization heat of water at $0{ }^{\circ} \mathrm{C} ; 2,500,000[\mathrm{~J} / \mathrm{kg}]$

$q_{v e, k, m n} \quad$ time-average airflow rate of airflow $\left[\mathrm{m}^{3} / \mathrm{s}\right]$

$Q_{h t} \quad$ total heat transfer [kWh]

$Q_{B} \quad$ heating load of the analyzed building [kWh]

$Q_{g n} \quad$ total heat gains [kWh]

$Q_{\text {int }} \quad$ internal heat gains [kWh]

$Q_{\text {sol }} \quad$ solar heat gains [kWh]

$Q_{t} \quad$ latent heat transfer [W]

$Q_{t r} \quad$ total heat transfer by transmission [kWh]

$Q_{v e} \quad$ total heat transfer by ventilation $[\mathrm{kWh}]$

$R_{s e} \quad$ external surface heat resistance of the element $\left[\mathrm{m}^{2} \mathrm{~K} / \mathrm{W}\right]$

$t \quad$ duration of the calculation step [h]

$T \quad$ air temperature $[\mathrm{K}]$

$U_{c} \quad$ thermal transmittance of the element $\left[\mathrm{W} / \mathrm{m}^{2} \mathrm{~K}\right]$

$U_{i} \quad$ thermal transmittance of element $\mathrm{i}$ of the building envelope [W/ $\left.\left./ \mathrm{m}^{2} \mathrm{~K}\right)\right]$

$\Phi_{r, k} \quad$ extra heat flow due to thermal radiation to the sky from building element $\mathrm{k}[\mathrm{W}]$

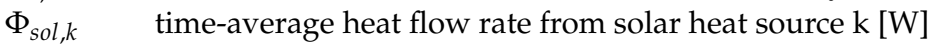

$\Phi_{\text {sol, } u, l}$

time-average heat flow rate from solar heat source $l$ in the adjacent unconditioned space [W]

$\Psi_{k} \quad$ linear thermal transmittance of thermal bridge $\mathrm{k}[\mathrm{W} /(\mathrm{mK})]$

$\eta_{H E}$ vent efficiency of the heat recovery unit

$\theta_{\text {In }} \quad$ air temperature at the GAHE outlet $\left[{ }^{\circ} \mathrm{C}\right]$

$\theta_{e} \quad$ temperature of the external environment $\left[{ }^{\circ} \mathrm{C}\right]$

$\theta_{\text {int.set }} \quad$ set-point temperature of the building (for heating or cooling) $\left[{ }^{\circ} \mathrm{C}\right]$

$\theta_{\text {sS }}$

$\theta_{\text {sup }, k}$

$\rho_{a} c_{a}$ arithmetic average of surface temperature and sky temperature $\left[{ }^{\circ} \mathrm{C}\right]$

supply temperature from the heat recovery unit $\left[{ }^{\circ} \mathrm{C}\right]$

heat capacity of air per volume; $1200\left[\mathrm{~J} /\left(\mathrm{m}^{3} \mathrm{~K}\right)\right]$

$\chi_{j} \quad$ point thermal transmittance of point bridge $\mathrm{j}[\mathrm{W} / \mathrm{K}]$

$\Delta \theta_{e r} \quad$ average difference between external air temperature and apparent sky temperature $\left[{ }^{\circ} \mathrm{C}\right]$

$\sigma \quad$ Stefan-Boltzmann constant; $5.67 \times 10^{-8}\left[\mathrm{~W} /\left(\mathrm{m}^{2} \mathrm{~K}^{4}\right)\right]$ 


\section{References}

1. European Commission. Energy Statistical Country Datasheets. Available online: https://ec.europa.eu/energy/data-analysis/ energy-statistical-pocketbook_en (accessed on 10 December 2021).

2. Ahmadi, M.M.; Keyhani, A.; Kalogirou, S.A.; Lam, S.S.; Peng, W.; Tabatabaei, M.; Aghbashlo, M. Net-zero exergoeconomic and exergoenvironmental building as new concepts for developing sustainable built environments. Energy Convers. Manag. 2021, 244, 114418. [CrossRef]

3. Buildings Performance Institute Europe (BPIE). On the Way to a Climate-Neutral Europe-Contributions from the Building Sector to a Strengthened 2030 Climate Target; BPIE: Bishnupur, India, 2020.

4. European Commission. Renovatin Wave. Available online: https://ec.europa.eu/commission/presscorner/detail/en/IP_20_183 5 (accessed on 9 December 2021).

5. Chenari, B.; Carrilho, J.D.; da Silva, M.G. Towards sustainable, energy-efficient and healthy ventilation strategies in buildings: A review. Renew. Sustain. Energy Rev. 2016, 59, 1426-1447. [CrossRef]

6. Franco, A.; Schito, E. Definition of optimal ventilation rates for balancing comfort and energy use in indoor spaces using $\mathrm{CO}_{2}$ concentration data. Buildings 2020, 10, 135. [CrossRef]

7. Zhang, H.; Yang, D.; Tam, V.W.; Tao, Y.; Zhang, G.; Setunge, S.; Shi, L. A critical review of combined natural ventilation techniques in sustainable buildings. Renew. Sustain. Energy Rev. 2021, 141, 110795. [CrossRef]

8. Cuce, E.; Sher, F.; Sadiq, H.; Cuce, P.M.; Guclu, T.; Besir, A.B. Sustainable ventilation strategies in buildings: CFD research. Sustain. Energy Technol. Assess. 2019, 36, 100540. [CrossRef]

9. Li, W.; Chen, Q. Design-based natural ventilation cooling potential evaluation for buildings in China. J. Build. Eng. 2021, 41, 102345. [CrossRef]

10. Poh, H.J.; Chiu, P.H.; Nguyen, H.H.; Xu, G.; Chong, C.S.; Lee, L.T.; Wong, N.C. Airflow Modelling Software Development for Natural Ventilation Design-Green Building Environment Simulation Technology. In IOP Conference Series: Earth and Environmental Science; IOP Publishing: Bristol, UK, 2019; Volume 238, p. 012077.

11. Dabaieh, M.; Serageldin, A.A. Earth air heat exchanger, Trombe wall and green wall for passive heating and cooling in premium passive refugee house in Sweden. Energy Convers. Manag. 2020, 209, 112555. [CrossRef]

12. Chen, Y.; Tong, Z.; Malkawi, A. Investigating natural ventilation potentials across the globe: Regional and climatic variations. Build. Environ. 2017, 122, 386-396. [CrossRef]

13. Solgi, E.; Hamedani, Z.; Fernando, R.; Skates, H.; Orji, N.E. A literature review of night ventilation strategies in buildings. Energy Build. 2018, 173, 337-352. [CrossRef]

14. Landsman, J. Performance, Prediction and Optimization of Night Ventilation across Different Climates; eScholarship Publishing: Irvine, CA, USA, 2016.

15. Liu, J.; Liu, Y.; Yang, L.; Liu, T.; Zhang, C.; Dong, H. Climatic and seasonal suitability of phase change materials coupled with night ventilation for office buildings in Western China. Renew. Energy 2020, 147, 356-373. [CrossRef]

16. Yao, R.; Li, B.; Steemers, K.; Short, A. Assessing the natural ventilation cooling potential of office buildings in different climate zones in China. Renew. Energy 2009, 34, 2697-2705. [CrossRef]

17. Guillén-Lambea, S.; Rodríguez-Soria, B.; Marín, J.M. Review of European ventilation strategies to meet the cooling and heating demands of nearly zero energy buildings (nZEB)/Passivhaus. Comparison with the USA. Renew. Sustain. Energy Rev. 2016, 62, 561-574. [CrossRef]

18. Laverge, J.; Janssens, A. Heat recovery ventilation operation traded off against natural and simple exhaust ventilation in Europe by primary energy factor, carbon dioxide emission, household consumer price and exergy. Energy Build. 2012, 50, 315-323. [CrossRef]

19. De Almeida, A.; Fong, J.; Brunner, C.U.; Werle, R.; Van Werkhoven, M. New technology trends and policy needs in energy efficient motor systems-A major opportunity for energy and carbon savings. Renew. Sustain. Energy Rev. 2019, 115, 109384. [CrossRef]

20. Hati, A.S. A comprehensive review of energy-efficiency of ventilation system using Artificial Intelligence. Renew. Sustain. Energy Rev. 2021, 146, 111153.

21. Roostaie, S.; Nawari, N.; Kibert, C.J. Sustainability and resilience: A review of definitions, relationships, and their integration into a combined building assessment framework. Build. Environ. 2019, 154, 132-144. [CrossRef]

22. Peretti, C.; Zarrella, A.; De Carli, M.; Zecchin, R. The design and environmental evaluation of earth-to-air heat exchangers (EAHE). A literature review. Renew. Sustain. Energy Rev. 2013, 28, 107-116. [CrossRef]

23. Bordoloi, N.; Sharma, A.; Nautiyal, H.; Goel, V. An intense review on the latest advancements of Earth Air Heat Exchangers. Renew. Sustain. Energy Rev. 2018, 89, 261-280. [CrossRef]

24. Taurines, K.; Girous-Julien, S.; Menezo, C. Energy and thermal analysis of an innovative earth-to-air heat exchanger: Experimental investigations. Energy Build. 2019, 187, 1-15. [CrossRef]

25. Lapertot, A.; Cuny, M.; Kadoch, B.; Le Métayer, O. Optimization of an earth-air heat exchanger combined with a heat recovery ventilation for residential building needs. Energy Build. 2021, 235, 110702. [CrossRef]

26. Hegazi, A.A.; Abdelrehim, O.; Khater, A. Parametric Optimization of Earth-Air Heat Exchangers (EAHEs) for Central Air Conditioning. Int. J. Refrig. 2021, 129, 278-289. [CrossRef]

27. Akbarpoor, A.M.; Poshtiri, A.H.; Biglari, F. Performance analysis of domed roof integrated with earth-to-air heat exchanger system to meet thermal comfort conditions in buildings. Renew. Energy 2021, 168, 1265-1293. [CrossRef] 
28. Li, Y.; Long, T.; Bai, X.; Wang, L.; Li, W.; Liu, S.; Huang, S. An experimental investigation on the passive ventilation and cooling performance of an integrated solar chimney and earth-air heat exchanger. Renew. Energy 2021, 175, 486-500. [CrossRef]

29. Pouranian, F.; Akbari, H.; Hosseinalipour, S.M. Performance assessment of solar chimney coupled with earth-to-air heat exchanger: A passive alternative for an indoor swimming pool ventilation in hot-arid climate. Appl. Energy 2021, 299, 117201. [CrossRef]

30. Qin, D.; Liu, J.; Zhang, G. A novel solar-geothermal system integrated with earth-to-air heat exchanger and solar air heater with phase change material-Numerical modelling, experimental calibration and parametrical analysis. J. Build. Eng. 2021, $35,101971$. [CrossRef]

31. D'Agostino, D.; Greco, A.; Masselli, C.; Minichiello, F. The employment of an earth-to-air heat exchanger as pre-treating unit of an air conditioning system for energy saving: A comparison among different worldwide climatic zones. Energy Build. 2020, 229, 110517. [CrossRef] [PubMed]

32. Rosa, N.; Soares, N.; Costa, J.J.; Santos, P.; Gervásio, H. Assessment of an earth-air heat exchanger (EAHE) system for residential buildings in warm-summer Mediterranean climate. Sustain. Energy Technol. Assess. 2020, 38, 100649. [CrossRef]

33. Baglivo, C.; Congedo, P.M.; Laforgia, D. Air cooled heat pump coupled with Horizontal Air-Ground Heat Exchanger (HAGHE) for Zero Energy Buildings in the Mediterranean climate. Energy Procedia 2017, 140, 2-12. [CrossRef]

34. Hsu, C.Y.; Huang, P.C.; Liang, J.D.; Chiang, Y.C.; Chen, S.L. The in-situ experiment of earth-air heat exchanger for a cafeteria building in subtropical monsoon climate. Renew. Energy 2020, 157, 741-753. [CrossRef]

35. Ahmed, S.F.; Khan, M.M.K.; Amanullah, M.T.O.; Rasul, M.G.; Hassan, N.M.S. A parametric analysis of the cooling performance of vertical earth-air heat exchanger in a subtropical climate. Renew. Energy 2021, 172, 350-367. [CrossRef]

36. Wei, H.; Yang, D.; Wang, J.; Du, J. Field experiments on the cooling capability of earth-to-air heat exchangers in hot and humid climate. Appl. Energy 2020, 276, 115493. [CrossRef]

37. Domingues, A.M.B.; Nobrega, E.S.B.; Ramalho, J.V.A.; Brum, R.S.; Quadros, R.S. Parameter analysis of Earth-air heat exchangers over multi-layered soils in South Brazil. Geothermics 2021, 93, 102074. [CrossRef]

38. Bisoniya, T.S.; Kumar, A.; Baredar, P. Experimental and analytical studies of earth-air heat exchanger (EAHE) systems in India: A review. Renew. Sustain. Energy Rev. 2013, 19, 238-246. [CrossRef]

39. Zajch, A.; Gough, W.A.; Yoon, G. Influence of daily temperature behavior on earth-air heat exchangers: A case study from Aichi, Japan. City Environ. Interact. 2020, 8, 100054. [CrossRef]

40. Woodson, T.; Coulibaly, Y.; Traoré, E.S. Earth-air heat exchangers for passive air conditioning: Case study Burkina Faso. J. Constr Dev. Ctries. 2012, 17, 21-32.

41. Chiesa, G.; Zajch, A. Contrasting climate-based approaches and building simulations for the investigation of Earth-to-air heat exchanger (EAHE) cooling sensitivity to building dimensions and future climate scenarios in North America. Energy Build. 2020, 227, 110410. [CrossRef]

42. Skotnicka-Siepsiak, A. Operation of a tube GAHE in Northeastern Poland in spring and summer-A comparison of real-world data with mathematically modeled data. Energies 2020, 13, 1778. [CrossRef]

43. Ozgener, L. A review on the experimental and analytical analysis of earth to air heat exchanger (EAHE) systems in Turkey. Renew. Sustain. Energy Rev. 2011, 15, 4483-4490. [CrossRef]

44. Wei, H.; Yang, D.; Du, J.; Guo, X. Field experiments on the effects of an earth-to-air heat exchanger on the indoor thermal environment in summer and winter for a typical hot-summer and cold-winter region. Renew. Energy 2021, 167, 530-541. [CrossRef]

45. Pakari, A.; Ghani, S. Performance evaluation of a near-surface earth-to-air heat exchanger with short-grass ground cover: An experimental study. Energy Convers. Manag. 2019, 201, 112163. [CrossRef]

46. Kaushal, M. Performance analysis of clean energy using geothermal earth to air heat exchanger (GEAHE) in Lower Himalayan Region-Case study scenario. Energy Build. 2021, 248, 111166. [CrossRef]

47. Kaushal, M. Geothermal cooling/heating using ground heat exchanger for various experimental and analytical studies: Comprehensive review. Energy Build. 2017, 139, 634-652. [CrossRef]

48. Brata, S.; Tanasa, C.; Stoian, V.; Stoian, D.; Dan, D.; Pacurar, C.; Brata, S. Measured and calculated energy saving on ventilation of a residential building equipped with ground-air heat exchanger. In E3S Web of Conferences; EDP Sciences: Les Ulis, France, 2019; Volume 111, p. 06074.

49. Pfafferott, J. Evaluation of earth-to-air heat exchangers with a standardised method to calculate energy efficiency. Energy Build. 2003, 35, 971-983. [CrossRef]

50. Mihalakakou, G.; Souliotis, M.; Papadaki, M.; Halkos, G.; Paravantis, J.; Makridis, S.; Papaefthimiou, S. Applications of earth-to-air heat exchangers: A holistic review. Renew. Sustain. Energy Rev. 2021, 111921. [CrossRef]

51. Tahery, D.; Roshandel, R.; Avami, A. An integrated dynamic model for evaluating the influence of ground to air heat transfer system on heating, cooling and $\mathrm{CO}_{2}$ supply in Greenhouses: Considering crop transpiration. Renew. Energy 2021, $173,42-56$. [CrossRef]

52. Astina, I.M.; Nugraha, M.Y. Numerical simulation of earth-air heat exchanger application for Indonesian simple house air conditioning system. Case Stud. Therm. Eng. 2021, 28, 101371. [CrossRef]

53. Taurines, K.; Giroux-Julien, S.; Farid, M.; Ménézo, C. Numerical modelling of a building integrated earth-to-air heat exchanger. Appl. Energy 2021, 296, 117030. [CrossRef] 
54. D'Agostino, D.; Esposito, F.; Greco, A.; Masselli, C.; Minichiello, F. The energy performances of a ground-to-air heat exchanger: A comparison among Köppen climatic areas. Energies 2020, 13, 2895. [CrossRef]

55. PN-EN 12831-1:2017-08; Energy Performance of Buildings-Method for Calculation of the Design Heat Load-Part 1: Space Heating Load, Module M3-3. DAV Publishing: Delhi, India, 2017.

56. PN-EN ISO 7730:2006; Ergonomics of the Thermal Environment-Analytical Determination and Interpretation of Thermal Comfort Using Calcula-tion of the PMV and PPD Indices and Local Thermal Comfort Criteria (ISO 7730:2005). ISO: Geneva, Switzerland, 2005.

57. ISO 13790:2008; Energy Performance of Buildings-Calculation of Energy Use for Space Heating and Cooling. ISO: Geneva, Switzerland, 2008.

58. Liu, Z.; Yu, Z.J.; Yang, T.; Li, S.; El Mankibi, M.; Roccamena, L.; Zhang, G. Designing and evaluating a new earth-to-air heat exchanger system in hot summer and cold winter areas. Energy Procedia 2019, 158, 6087-6092. [CrossRef]

59. Li, H.; Ni, L.; Yao, Y.; Sun, C. Experimental investigation on the cooling performance of an Earth to Air Heat Exchanger (EAHE) equipped with an irrigation system to adjust soil moisture. Energy Build. 2019, 196, 280-292. [CrossRef]

60. Raport IMGW-PIB: Klimat Polski. 2020. Available online: https://imgw.pl/sites/default/files/flipbook/klimat_2020/imgwpib_klimat_polski_2020.html\#p=6 (accessed on 17 July 2021).

61. Ma, G.; Liu, T.; Shang, S. Improving the climate adaptability of building green retrofitting in different regions: A weight correction system for Chinese national standard. Sustain. Cities Soc. 2021, 69, 102843. [CrossRef]

62. Bzowska, D. Ryzyko przegrzania budynków izolowanych cieplnie w okresie letnim. Czas. Inżynierii Lądowej Sr. Archit. 2016, 63, 43-52. [CrossRef]

63. Kisilewicz, T. Wpływ Izolacyjnych, Dynamicznych i Spektralnych Właściwości Przegród na Bilans Cieplny Budynków Energooszczędnych; Wydawnictwo Politechniki Krakowskiej: Kraków, Polska, 2008.

64. Choi, Y.H.; Song, D.; Seo, D.; Kim, J. Analysis of the variable heat exchange efficiency of heat recovery ventilators and the associated heating energy demand. Energy Build. 2018, 172, 152-158. [CrossRef]

65. Estrada, E.; Labat, M.; Lorente, S.; Rocha, L.A. The impact of latent heat exchanges on the design of earth air heat exchangers. Appl. Therm. Eng. 2018, 129, 306-317. [CrossRef]

66. Niu, F.; Yu, Y.; Yu, D.; Li, H. Heat and mass transfer performance analysis and cooling capacity prediction of earth to air heat exchanger. Appl. Energy 2015, 137, 211-221. [CrossRef] 